\title{
IMPLICATION OF RADIOCARBON DATES FROM SOHR DAMB/NAL, BALOCHISTAN
}

\author{
Jochen Görsdorf \\ German Institute of Archaeology, Division of Natural Science, Im Dol 2-6 D-14195 Berlin, Germany. \\ Ute Franke-Vogt \\ German Institute of Archaeology, Eurasia Department, Im Dol 2-6, D-14195 Berlin, Germany.
}

\begin{abstract}
Sohr Damb/Nal, the type site of the Nal complex, is located in Balochistan, Pakistan. After 1 season of excavation by $\mathrm{H}$ Hargreaves in 1924, which made the polychrome Nal pottery widely known, no further work took place until the Joint German-Pakistani Archaeological Mission to Kalat resumed excavations in 2001. So far, 4 seasons of excavations have been undertaken, which have revealed 4 periods of occupation, dated from about 3800 to $2000 \mathrm{BC}$. The well-stratified assemblages provide new insights into cultural processes and developments, and enhance the comparative frameworks through typological series and a comprehensive set of radiocarbon dates. This information is essential for assessing cross-cultural relations and the date of urbanization. In this paper, the ${ }^{14} \mathrm{C}$ dates from Sohr Damb/Nal are presented and their cultural context is discussed. Period III has several links to sites in Pakistan, Afghanistan, and Iran, such as Miri Qalat IIIb-c, Mehrgarh VI-VII/ Nausharo I, Quetta III, Mundigak IV, and Shahr-e Sokhta II-III. Period IV represents a Kulli-Harappan occupation, which is dated to the second half of the 3 rd millennium BC.
\end{abstract}

\section{INTRODUCTION}

Sohr Damb/Nal is a 4.5-ha-large, 13-m-high mound located in highland Balochistan, in the borderlands between Iran, Afghanistan, and Pakistan, and between the Indus plains and the Iranian Plateau. Since the first investigations were carried out in the early 20th century (Marshall 1904-5; Hargreaves 1929; Stein 1931), this has been the type site for one of the cultural complexes that characterize the cultural development in this region from 4000 to 2000 BC: Togau, Kechi Beg, Nal, Quetta, and Kulli. The Nal horizon is characterized by a pottery that technologically and stylistically is among the most remarkable productions of the 3rd millennium BC wares throughout the region. The lack of contextual and stratigraphic information about the overall material culture and its typological range, and thus about the regional "cultural landscape," has, however, so far prevented putting these materials into context (Possehl 1999; Franke-Vogt and Ibrahim 2005).

In response to the need for large-scale excavations in Balochistan, a project was started in 2001 in collaboration with the Department of Antiquities and Museum, Pakistan, with funds from the German Research Society. The work brought to light a rich and well-stratified cultural assemblage. In $2005,1750 \mathrm{~m}^{2}$ were excavated in 9 trenches and a sequence with 4 main periods and several subphases has been established (Franke-Vogt 2005a,b). Already in 2001, it became clear that the site was occupied longer than previously assumed. The Nal layers of Period II are sandwiched by 1 older and 2 younger occupations, and the duration of the settlement is now dated from $4000 / 3800 \mathrm{BC}$ to 2300/2200 BC.

This new evidence not only facilitates typological and technological studies, but also investigations into architecture, arts, technology, environment, and settlement patterns. In addition to extensive archaeobotanical and -zoological studies that provide information on the ancient environment, climate, and subsistence economy (Benecke and Neef 2005), a wide range of radiocarbon samples was analyzed (Görsdorf 2003, 2004, 2005a,b, forthcoming). For the first time, a well-stratified series of ${ }^{14} \mathrm{C}$ dates is available from this area and, along with the information from sites such as Mehrgarh/ Nausharo, Miri Qalat, and Shahi Tump (Jarrige et al. 1995; Besenval 1997, 2005), a more reliable relative and absolute chronological framework can now be established. Apart from development through time, regional variation now becomes more clear. Evaluation of the data will facilitate the 
reconstruction of the cultural, or conceptual, landscapes and of cultural developments through time. One question that can now also be addressed, taking a view from Sohr Damb, is the date of the first urban civilization in southeastern Iran and Afghanistan, represented by sites such as Shahr-e Sokhta II/III and Mundigak. Controversially discussed and dated to 2500 and $~ 2300 / 2200$, respectively, it is still an open question whether the end of this horizon was contemporary with or earlier than the Indus civilization that emerged after 2600 BC in the Indus plains (Besenval 2005; Salvatori and Tosi 2005).

\section{RESULTS AND DISCUSSION}

\section{Period I}

Period I belongs to a time around $4000 \mathrm{BC}$ when the number of sites rose throughout the region, and when the eastern piedmont of the Kirthar Range and the Indus Valley proper were settled (FrankeVogt 2001). Sohr Damb was founded on a gravel accumulation near a small river. The earliest occupation, found underneath Hargreaves' excavations, is mainly represented by a cemetery that has so far yielded 11 tombs. The squarish chambers measure up to $1.5 \mathrm{~m} \times 1.5 \mathrm{~m}$ and are built with pisé and mud-brick walls. The interior is often divided into 2 compartments, separated by a small wall. All tombs contain a large number of grave goods and the remains of up to 16 individuals: In Tomb 739/ 740 , more than 12 bodies and 60 complete pots were found. All chambers contain multiple fractional burials, deposited some time after death. The pottery belongs to different cultural styles, such as Togau A-D, Kile Ghul Mohammad, and Kechi Beg, which were previously believed to represent development through time. Their association thus highlights the need for a re-investigation of the relative typological sequence. Due to the lack of ${ }^{14} \mathrm{C}$ samples, the date of Period I is based on the comparative evidence, although a reliable framework is not available. The assemblage is comparable to Mehrgarh III-IV and Shahi Tump in Makran, but the differences in burial customs and grave goods are pronounced. Some parallels can also be drawn to the Sialk III horizon in Iran. Presently, a date between $4000 / 3800$ and $3200 \mathrm{BC}$ is proposed.

\section{Period II}

Since its discovery, the stratigraphy and context of Hargreaves' (1929) findings have remained unclear. It was only in 2004 that levels of a Nal settlement were found that helped to establish an idea of what the Nal horizon is in terms of style and context. Since then, the comparative evidence is supported by a growing number of ${ }^{14} \mathrm{C}$ dates from stratified deposits.

The settlement reached its present size of 4.5 ha. The older cemetery was leveled for new buildings and the tombs were partly destroyed. Burial customs changed from multiple fractional to complete individual inhumations. In the living quarters, the houses are built next to each other and rooms are small but with many installations, such as basins with lime floors, hearths, brick platforms, and storage jars. Structurally, we can distinguish 3 building phases. The rooms were filled with brick debris and soil, but the mud-brick walls are preserved to a height of $1.5 \mathrm{~m}$. Domestic utensils still lay on the floor, among them grinding stones, pestles, mortars, and storage jars. They indicate that food storage and preparation took place there. Other items include cattle figurines and beads made of carnelian, lapis lazuli, and heat-treated steatite paste.

Several changes of technology and style can be observed, although black or red slipped pottery types are still present. These vessels carry the oldest graffiti, usually 1, sometimes 2 signs painted in white on the slip or scratched into the surface. The Togau pottery, which was so common in Period I, was no longer produced. The typical Nal pottery is buff and carries complex geometric and figurative motifs painted in black, and often with turquoise, yellow, and red as additional colors. 
From Period II, $12{ }^{14} \mathrm{C}$ dates have been obtained ( 10 charcoal samples, 1 wood sample, and 1 wood and charcoal sample) (Görsdorf 2003, 2004, 2005a, forthcoming). The calibrated results for this period are shown in Figure 1. The calibration program OxCal v 3.10 (Bronk Ramsey 1995, 2001) with the IntCal04 calibration curve (Reimer et al. 2004) was used to calibrate all samples. The dates cluster between $3100 \mathrm{BC}$ and $2700 \mathrm{BC}$, a range that fits the overall chronological scheme well, although the initial date is a little older than thus far assumed for the Nal period, especially since the samples do not come from the lowest Period II levels. We think that the high ages of the samples $\mathrm{B} \ln -5384$ and $\mathrm{B} \ln -5760$ are due to the plateau in the calibration curve.

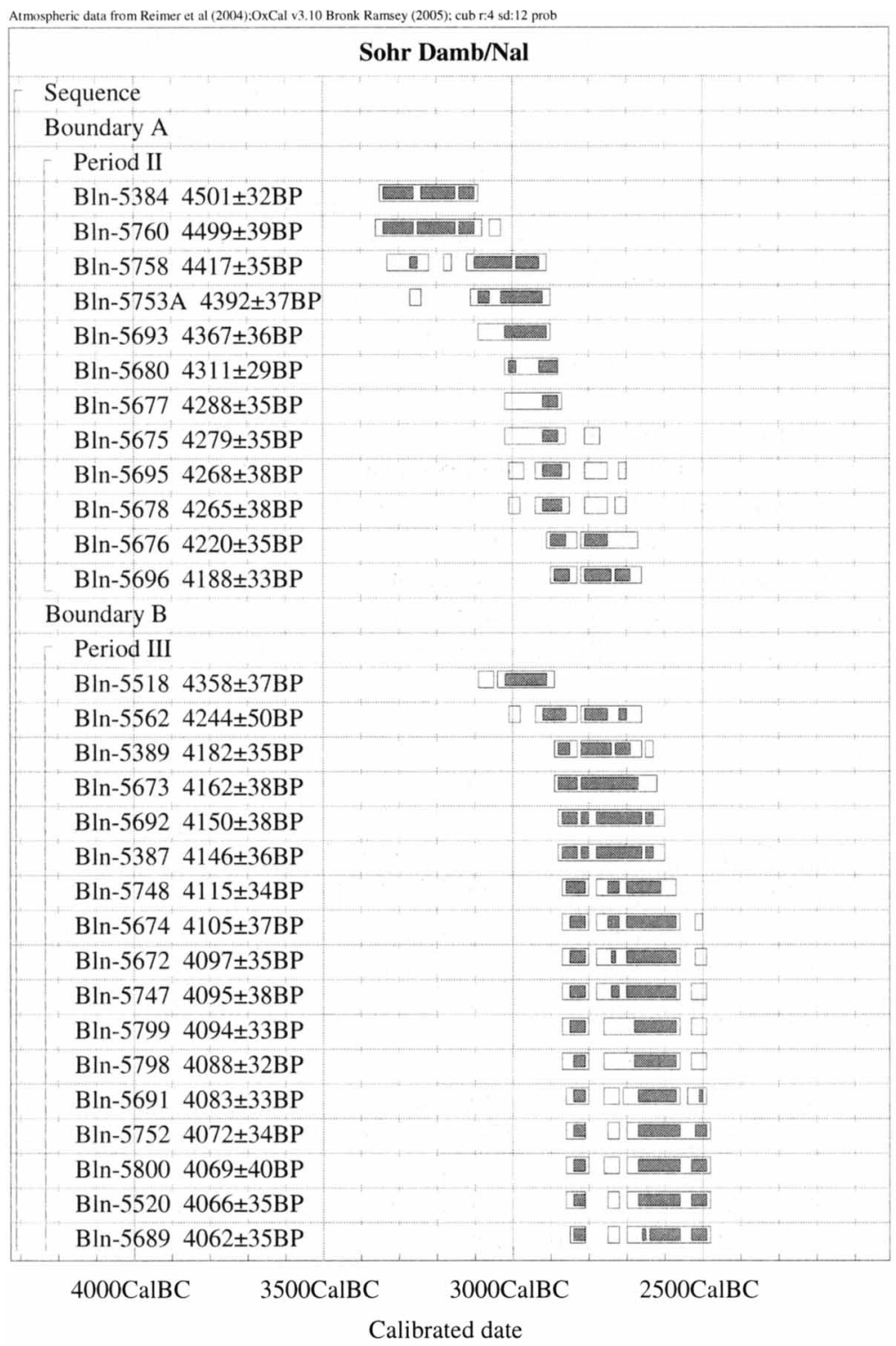

Figure 1 Calibration of dating results (Period II and part of III) with the program OxCal v 3.10 . The confidence limit of the smaller, hatched boxes is $68.2 \%$, and $95.4 \%$ for the broader boxes. 


\section{Period III}

The houses of Period II were abandoned and fell into decay before a new settlement was built. The buildings of Period III cover most of the present mound, but not all areas were occupied at the same time. A modeled topography and a complex sequence of layers reveals that some plots were used as garbage dumps for pottery, bones, ashes, and building debris while others were inhabited. Thus, even adjacent trenches may have a different stratigraphic sequence. The processes of settlement growth and regression during this period will only be clear after all trenches are stratigraphically linked to the sequence established in Trench I. Here, next to Trench D, excavated by Hargreaves in 1925 , a total of 17 buildings were uncovered that belong to at least 4 phases with 21 levels. They differ in size and dimensions as well as in building techniques from Period II architecture. Rooms are larger, walls more wide and compact, and they rest on gravel foundations and wooden beams (tamarisks, acacia). The largest building is the "Burnt Building" (AK 6), where in 2 superimposed horizons hundreds of vessels and objects were found. The pottery belongs to different stylistic traditions, in particular Rana Ghundai III and Quetta III, along with a few early Kulli features, but the assemblage has, in general, a strong local expression. Several grinding stones and tools attest to a domestic use of the rooms, but stone tools for leather working, unbaked and baked large and small terra-cotta bulls, and beads indicate a multifunctional use of the area. Miniature clay vessels, crucibles, and moulds as well as lead platelets imply metal working, but, despite nearby copper and lead mines, metal objects are rare (Yule 1995).

The transition from Period II to III is again marked by pronounced changes in style and technology. Only a few ornaments reappear in a different form and execution, and one must wonder whether their meaning and symbolic concept was also transferred. Neither polychrome nor monochrome Nal wares were still produced. The whole operational chain of pottery production is different, more simple and plain, and besides new shapes and motifs new tools were introduced, such as moulds and chucks. This change in style is accompanied by a stratigraphic hiatus in most areas, marked either by leveling layers or by thick ash and sand deposits that buried the collapsed and eroded houses of Period II.

The discovery of a settlement dating to this time is important since crucial developments took place from 2800/2700 onwards throughout the borderlands: Mundigak IV reached its largest size; Shahre Sokhta (II-III) grew into an urban center with monumental architecture; and in the Indus Valley, after $2600 \mathrm{BC}$, a centralized state took shape that gradually expanded over a huge area, and extended its sphere of interest to the resource-rich areas in Afghanistan, Balochistan, and Oman. The borderlands were then linked through a horizon that extended from northern Balochistan (Quetta III, Sadaat, Rana Ghundai III, Sohr Damb III), to the Kachhi plain (Mehrgarh VIIB-C, Nausharo IAD), Afghanistan (Mundigak IV), southeastern Iran (Shahr-e Sokhta II/III), and western Makran (Miri IIIb-c).

While the comparative chronology is well established, the absolute chronological framework of this particular period is controversial, with implications for questions such as which entities participated in these cross-cultural relations, what impact did that have on their development, and how long did these cities exist. If the end of the urban period at Shahr-e Sokhta dates to the late 3rd millennium BC, as suggested by the Italian mission (Biscione 1990; Salvatori and Tosi 2005), it overlapped with the Indus civilization (about 2600-1900 BC) and the Akkadian Empire in the west. If dated to the mid-3rd millennium, as suggested by the French missions (Jarrige 1993; Besenval 2005), this horizon already came to an end at the very beginning of the Indus civilization and before the rise of the Akkadian Empire. 
The evidence from Balochistan favors the shorter chronology. First, while southeastern Iran had strong relations with Mesopotamian markets during the earlier Early Dynastic periods, archaeological evidence for contacts with the Indus Valley is required on both sides. Considering the largescale exposures in both areas, this negative evidence is hardly due to random chance alone. Secondly, the late date is in conflict with the comparative evidence from Balochistan where the horizon that links these sites belongs to the Early Harappan period, preceding the Indus period. Most recently, at Sohr Damb a transitional horizon was found in Period III deposits in Trench IX that links these layers with Nausharo ID and Miri Qalat IIIc, transitional layers just preceding the Harappan Period, but anticipating already many Indus features and datable to a short and precise period in time, namely about 2600-2500 BC. The Harappan occupations found on top of these levels at Nausharo II and Miri Qalat IV narrow the lower chronological margins, even if we provide a certain time range for the spread of similar cultural styles over a large region. Thirdly, a new series of ${ }^{14} \mathrm{C}$ dates from Sohr Damb supports the date of this comparative evidence.

We have $59{ }^{14} \mathrm{C}$ dates from well-stratified deposits in Trench I, predominantly from the 2 uppermost of the 4 phases of this period ( 48 charcoal samples, 10 wood samples, and 1 wood and charcoal sample; Görsdorf 2003, 2004, 2005a, forthcoming). The calibrated results for Period III are shown in Figures 1 and 2. They show a clear cluster from 2700 to $2500 / 2400 \mathrm{BC}$, leaving no doubt that the terminal date of Period III is not much later than $\sim 2400 \mathrm{BC}$. The sample size is large enough to adjust for the few dates that lie beyond this range. Such a date also leaves room for Period IV, which belongs to the so-called Kulli-Harappan horizon, the hallmark of southern Balochistan during the later 3rd millennium BC (see below).

This dating also corresponds well with the relative sequences from Nausharo and Miri Qalat, where the Indus occupations belong to the earlier rather than the later Indus period. It is stratigraphically and culturally well associated at Nausharo, but based on stylistic criteria only at Miri Qalat where the ${ }^{14} \mathrm{C}$ dates cluster during the late 3rd millennium BC (Besenval 2005). The dates from Shahr-e Sokhta are still not clear, despite their recent re-assessment (Salvatori and Tosi 2005). They are few in number and their results are not coherent. The samples from the post-urban Phase 1 (Burnt Building), for example, lie between 2600 and 2200 and are as old as the dates from Phase 5 and older than the 3 dates from phases 4 to 2 .

\section{Period IV (Kulli-Harappan)}

Sohr Damb remained settled after Period III, but the Period IV occupation is very eroded and only attested at the surface, often just by gravel foundations. The pottery resembles so-called KulliHarappan types that are widely found all over southern Balochistan during the later 3rd millennium BC. It combines features of the indigenous Kulli complex with those of the Indus civilization and reflects the westerly expansion into the Kulli domain of this civilization (Possehl 1986; Franke-Vogt 2000, forthcoming; Quivron 2000). Period III types continue, indicating that different styles occurred side by side. The calibrated dating results of the few samples available from Period IV fall to between 2500 and 2300 and are later than the dates from Period III, as shown in Figure 2.

Up to now, the calibration of dating results was done without the integration of archaeological information. Taking these into account, we find that the sample that produced Bln-5518 is too old, while Bln-5390 is too young for Period III. Likewise, the result of Bln-5682 appears too old for Period IV. If a result is too old, there is a possibility that this error is caused by the old-wood effect. If a dating is too young, a contamination of dating material with younger material is possible. Without these problematical dates, we obtained the calibration results shown in Figure 3 and 4 . We get information about boundary B (the transition from Period II to III) and boundary C (the transition from Period III 


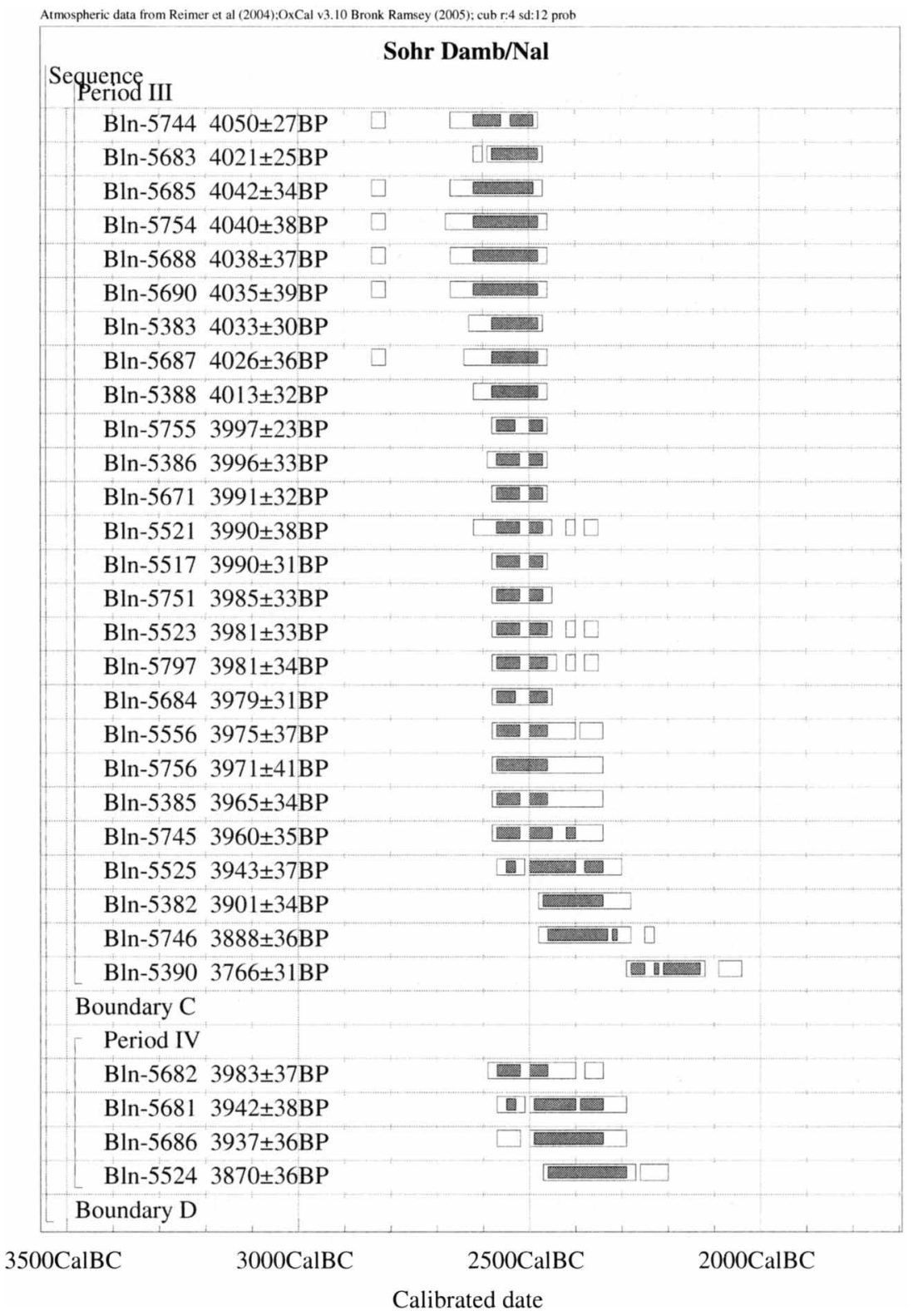

Figure 2 Calibration of dating results (part of periods III and IV) with the program OxCal v 3.10 .

The confidence limit of the smaller, hatched boxes is $68.2 \%$, and $95.4 \%$ for the broader boxes.

to Period IV). The probability distributions over time for the boundaries B (Figure 5) and C (Figure 6) are also shown.

Although the statistical analyses reveal that results from one and the same context can vary substantially, we feel that with a total of 59 samples from well-stratified contexts and marked clusters within a certain range of time, we are on safe ground to use these dates for adjusting the chronological scheme of this area in accordance with the comparative archaeological data. 
Atmospheric data from Reimer et al (2004); OxCal v3.10 Bronk Ramsey (2005); cub r:4 sd:12 prob

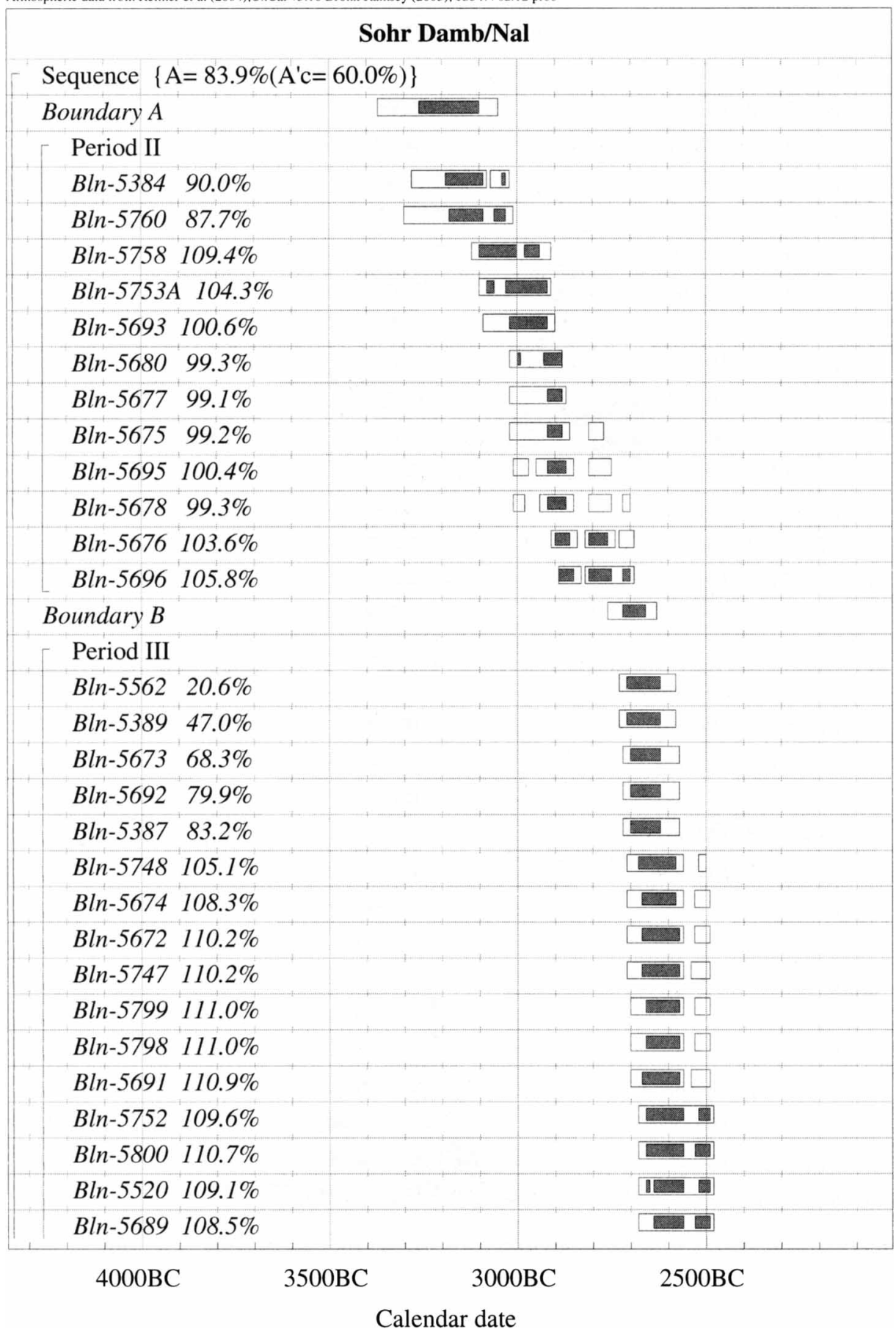

Figure 3 Calibration of dating results (periods II and part of III) with $\mathrm{OxCal} v 3.10$ in consideration of the stratigraphic and archaeological information, by using the Gibbs sampling method. The confidence limit of the smaller, hatched boxes is $68.2 \%$, and $95.4 \%$ for the broader boxes. 


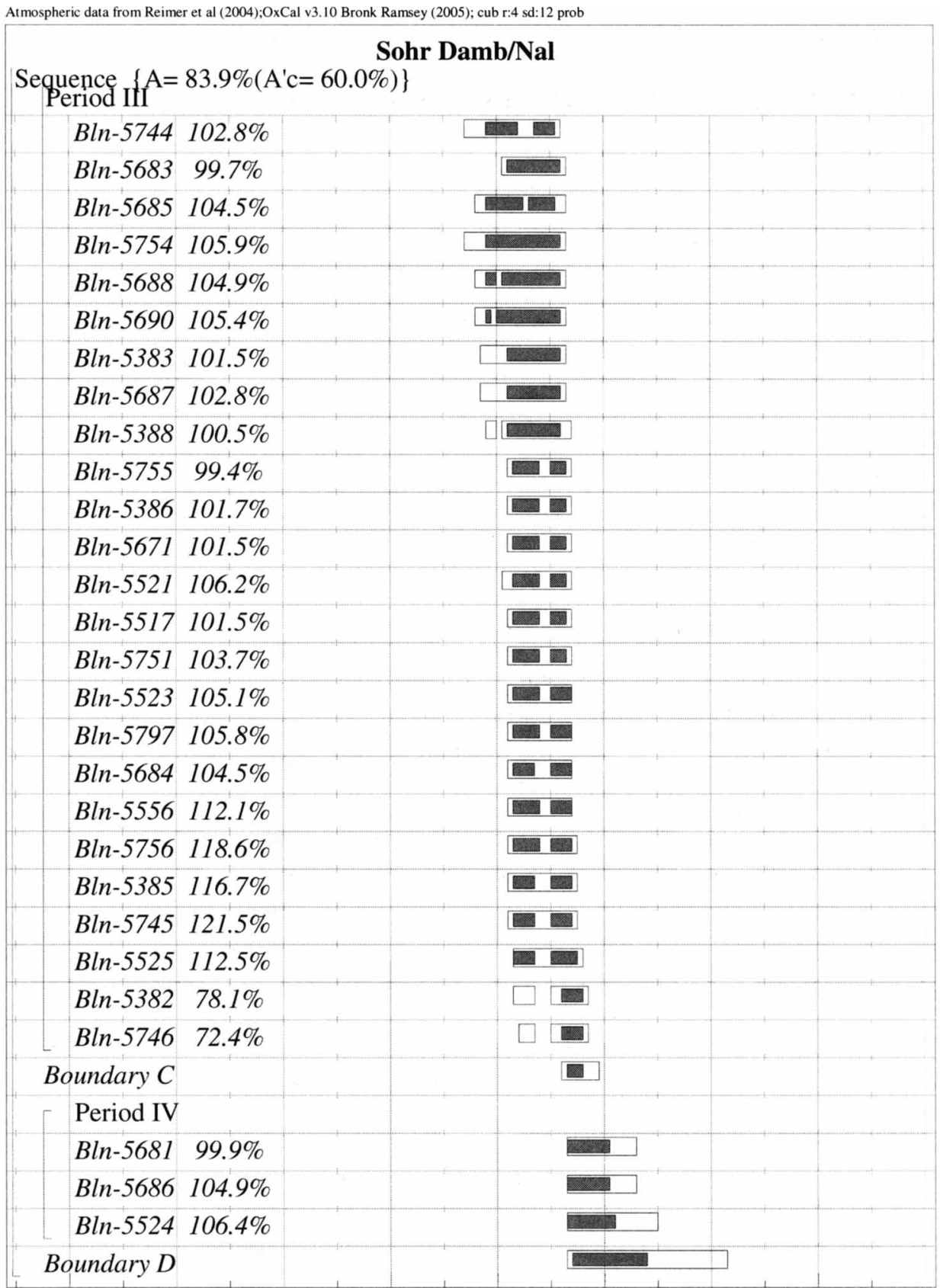

3400BC 3200BC 3000BC 2800BC 2600BC 2400BC 2200BC 2000BC 1800BC

Calendar date

Figure 4 Calibration of dating results (part of periods III and IV) with OxCal v 3.10 in consideration of the stratigraphic and archaeological information, by using the Gibbs sampling method. The confidence limit of the smaller, hatched boxes is $68.2 \%$, and $95.4 \%$ for the broader boxes. 


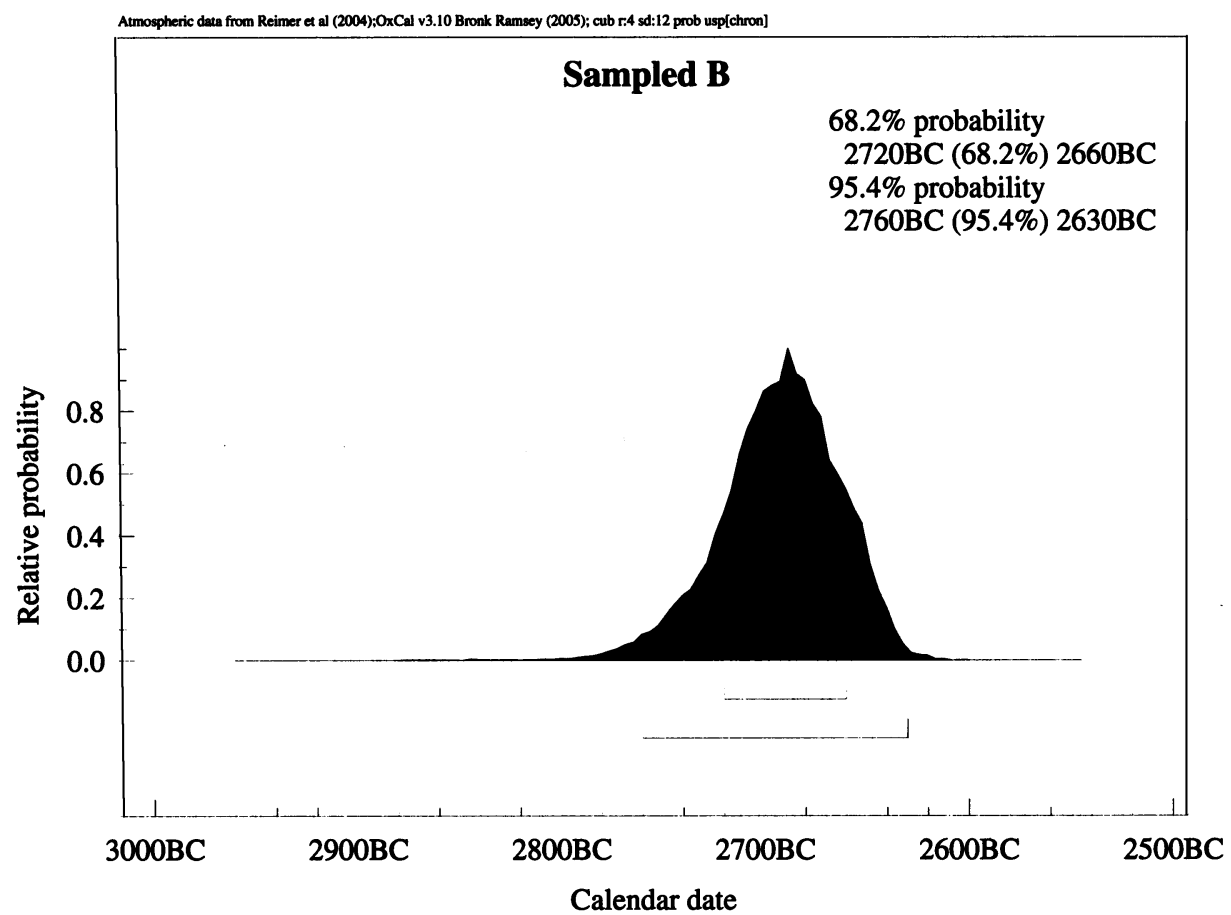

Figure 5 Probability distribution for boundary B

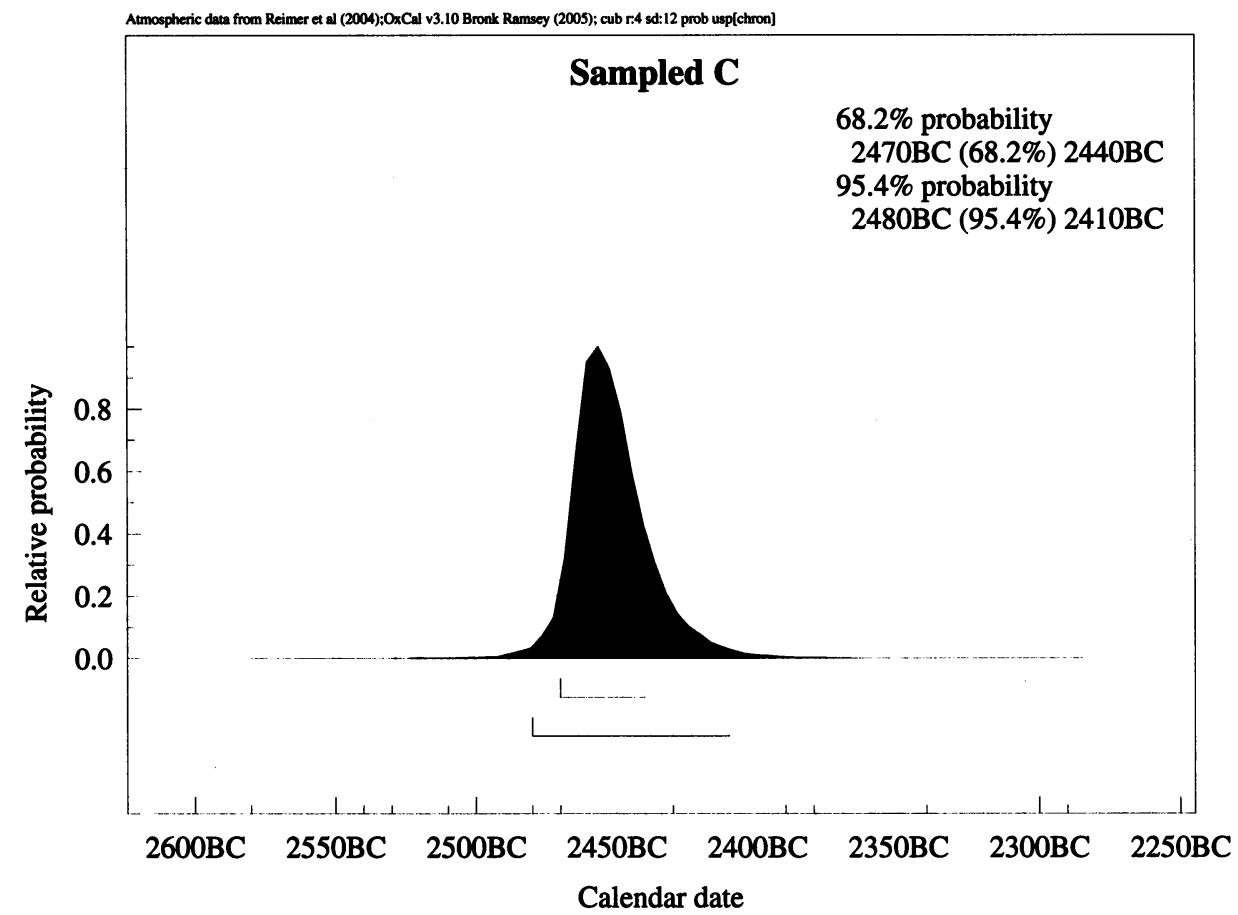

Figure 6 Probability distribution for boundary C 


\section{REFERENCES}

Benecke N, Neef R. 2005. Faunal and plant remains from Sohr Damb/Nal: a prehistoric site (c. 3500-2000 BC) in central Balochistan (Pakistan). In: Franke-Vogt U, Weishaar J, editors. South Asian Archaeology 2003. Aachen: Linden Soft. p 81-91.

Besenval R. 1997. Entre le Sud-Est iranien et la plaine de l'Indus: le Kech-Makran. Recherches archéologiques sur le peuplement ancien d'une marche des confins indo-iraniens. Arts Asiatiques 52:5-36. In French.

Besenval R. 2005. Chronology of Kech-Makran. In: Jarrige C, Lecomte O, editors. South Asian Archaeology 2001. Paris: ADPF Éditions Recherche sur les Civilisations. p 1-9.

Biscione R. 1990. The elusive phase 2 of the Shahr-i Sokhta sequence. In: Taddei M, editor. South Asian Archaeology 1987. Rome: Instituto Italiano per il Medio ed Estremo Oriente. p 391-410.

Bronk Ramsey C. 1995. Radiocarbon calibration and analysis of stratigraphy: the OxCal program. Radiocarbon 37(2):425-30.

Bronk Ramsey C. 2001. Development of the radiocarbon calibration program. Radiocarbon 43(2A):355-63.

Franke-Vogt U. 2000. The archaeology of southeastern Balochistan [WWW document with 130 photos]. URL: http://www.harappa.com/baluch.

Franke-Vogt U. 2001. Balakot: Kulturelle Interaktion und Integration während der Früh-Harappa-Phase in Südbalochistan (Pakistan) [Habilitationsschrift]. Berlin: Deutsches Archäologisches Institut. In German.

Franke-Vogt U. 2005a. Excavations at Sohr Damb/Nal: results of the 2002 and 2004 seasons. In: Franke-Vogt U, Weishaar J, editors. South Asian Archaeology 2003. Aachen: Linden Soft. p 63-76.

Franke-Vogt U. 2005b. Sohr Damb/Nal, Baluchistan, Pakistan Ergebnisse der Grabungen 2001, 2002 und 2004. Archäologische Mitteilungen aus Iran und Turan Band 35-36, 2003-2004. p 83-141. In German.

Franke-Vogt U. Forthcoming. Southeastern Balochistan during the later third millennium BC. In: Kenoyer JM, editor. Indus Valley Archaeology: Recent Research and New Directions. Madison: Wisconsin Archaeological Reports, University of Wisconsin, Madison. Volume 4.

Franke-Vogt U, Ibrahim A. 2005. A new perspective of an old site: reopening excavations at Sohr Damb/Nal (Balochistan). In: Jarrige C, Lecomte O, editors. South Asian Archaeology 2001. Paris: ADPF Éditions Recherche sur les Civilisations. p 105-15.

Görsdorf J. 2003. Datierungsergebnisse des Berliner ${ }^{14} \mathrm{C}$ Labors 2002. Eurasia Antiqua 9:359-66. In German.

Görsdorf J. 2004. Datierungsergebnisse des Berliner ${ }^{14} \mathrm{C}$ Labors 2003. Eurasia Antiqua 10:401-9. In German.

Görsdorf J. 2005a. Datierungsergebnisse des Berliner ${ }^{14}$ C-Labors 2004. Eurasia Antiqua 11:463-9. In Ger- man.

Görsdorf J. 2005b. Radiocarbon dates from Sohr Damb/ Nal, Balochistan. In: Franke-Vogt U, Weishaar J, editors. South Asian Archaeology 2003. Aachen: Linden Soft. p 77-80.

Görsdorf J. Forthcoming. Datierungsergebnisse des Berliner ${ }^{14} \mathrm{C}$-Labors 2005. Eurasia Antiqua 12.

Hargreaves H. 1929. Excavations in Baluchistan 1925. Sampur Mound, Mastung and Sohr Damb, Nal. New Delhi: Memoirs of the Archaeological Survey of India 35.

Jarrige C, Jarrige JF, Meadow RH, Quivron G, editors. 1995. Mehrgarh: Field Reports 1974-1985. From Neolithic Times to the Indus Civilization. Karachi: Department of Culture and Tourism, Government of Sindh. 688 p.

Jarrige JF. 1993. The question of the beginning of the mature Harappan civilization as seen from Nausharo excavations. In: Gail A, Mevissen G, editors. South Asian Archaeology 1991. Stuttgart: FS Verlag. p 14964.

Marshall JH. 1904-5. A New Type of Pottery from Baluchistan. New Delhi: Annual Reports of the Archaeological Survey of India 1904-5. p 105-6.

Possehl GL. 1986. Kulli: An Exploration of an Ancient Civilization in South Asia. Durham: Carolina Academic Press. 168 p.

Possehl GL. 1999. Indus Age. The Beginnings. Philadelphia: University of Pennsylvania Press. 950 p.

Quivron G. 2000. The evolution of the mature Indus pottery style in the light of excavations at Nausharo, $\mathrm{Pa}$ kistan. East and West 50(1-4):147-90.

Reimer PJ, Baillie MGL, Bard E, Bayliss A, Beck JW, Bertrand CJH, Blackwell PG, Buck CE, Burr GS, Cutler KB, Damon PE, Edwards RL, Fairbanks RG, Friedrich M, Guilderson TP, Hogg AG, Hughen KA, Kromer B, McCormac G, Manning S, Bronk Ramsey C, Reimer RW, Remmele S, Southon JR, Stuiver M, Talamo S, Taylor FW, van der Plicht J, Weyhenmeyer CE. 2004. IntCal04 terrestrial radiocarbon age calibration, 0-26 cal kyr BP. Radiocarbon 46(3): 1029-58.

Salvatori S, Tosi M. 2005. Shahr-e Sokhta revised sequence. In: Jarrige C, Lecomte O, editors. South Asian Archaeology 2001. Paris: ADPF Éditions Recherche sur les Civilisations. p 281-91.

Stein MA. 1931. An Archaeological Tour in Gedrosia. New Delhi: Memoirs of the Archaeological Survey of India 43.

Yule P. 1995. Silberne Grabbeigaben der Sohr Damb nahe Nal, Pakistan. In: Finkbeiner U, Dittmann R, Boehmer M, editors. Beiträge zur Kulturgeschichte Vorderasiens. Festschrift für Rainer Michael Boehmer. Mainz: von Zabern. p 691-8. In German. 